\title{
Clinical Evaluation of Using Three Different Materials in Primary Molar Class II Restorations
}

\author{
Süt Molar Dişlerinin Sınıf II Restorasyonlarında Üç Farklı \\ Materyalin Klinik Başarısının Değerlendirilmesi \\ (1) Şeyma Erdoğan ${ }^{1}$, (1D Işıl Sönmez ${ }^{2}$
}

${ }^{1}$ Gaziantep Şahinbey Oral and Dental Health Hospital, Clinic of Pedodontology, Gaziantep, Turkey

${ }^{2}$ Aydın Adnan Menderes University Faculty of Dentistry, Department of Pedodontology, Aydın, Turkey

Keywords

Primary molar teeth, compomer, glass carbomer cement, glass ionomer cement, restoration

\section{Anahtar Kelimeler}

Süt molar diş, kompomer, cam karbomer siman, cam iyonomer siman, restorasyon

Received/Geliş Tarihi : 21.10.2020

Accepted/Kabul Tarihi : 01.01.2021

doi:10.4274/meandros.galenos.2021.58966

Address for Correspondence/Yazışma Adresi: Şeyma Erdoğan MD,

Gaziantep Şahinbey Oral and Dental Health

Hospital, Clinic of Pedodontology, Gaziantep, Turkey

Phone : +90 5435032424

E-mail : seymerdogan24@gmail.com

ORCID ID: orcid.org/0000-0003-4311-4684

(C) Meandros Medical and Dental Journal, Published by Galenos Publishing House.

This is article distributed under the terms of the

Creative Commons Attribution NonCommercial 4.0

International Licence (CC BY-NC 4.0).

\begin{abstract}
Objective: This study aimed to compare the 12-month clinical performance of a glass carbomer cement (GCP glass fill), a glass hybrid cement (Equia Forte) and a compomer material (Dyract XP) in primary molar class II restorations.

Materials and Methods: The study was carried out on 105 primary molars with class II lesion in 35 children aged 6-9 years. Three different restorative materials were placed in each child. Restorations were evaluated according to the modified United States Public Health Service criteria after the first week and at sixth and $12^{\text {th }}$ months. Data obtained were evaluated statistically.

Results: After 12 months, 32 children were available and 96 restorations were evaluated. The clinical success of the compomer material, glass carbomer cement, and glass hybrid cement were $96.9 \%, 15.6 \%$, and 9.4\%, respectively.

Conclusion: After the 12-month treatment period, the clinical success of the compomer material was significantly higher than those of the glass carbomer cement and glass hybrid cement groups.
\end{abstract}

Öz

Amaç: Bu çalışmanın amacı süt dişi sınıf II restorasyonlarında bir cam karbomer siman (GCP Glass Fill), bir cam hibrid siman (Equia Forte) ve bir kompomer materyalin (Dyract XP) 12 aylık klinik performansının karşılaştırılmasıdır.

Gereç ve Yöntemler: Çalışma 6-9 yaş arası 35 çocuğun sınıf II çürüğü bulunan 105 adet süt molar dişinde yürütülmüştür. Tüm çocuklarda her 3 materyal de kullanılmıştır. Restorasyonlar 1. hafta, 6. ay ve 12. ay sonunda modifiye Birleşik Devletler Halk Sağlığı Servisi kriterleri ile skorlanarak, sonuçlar istatistiksel olarak değerlendirilmiştir.

Bulgular: On iki ay sonunda 32 çocukta 96 restorasyon değerlendirilebilmiştir. Grupların klinik başarısı sırasıyla; kompomer grubunda \%96,9, cam karbomer grubunda \%15 ve cam hibrid grubunda ise \%9,4 olarak bulunmuştur.

Sonuç: Kompomer materyalinin klinik başarısı 12 aylık takip sonunda hem cam karbomer hem de cam hibrid siman gruplarına göre istatistiksel olarak anlamlı düzeyde yüksek bulunmuştur. 


\section{Introduction}

In recent years, the studies on restorative materials used for the restoration of primary teeth are continuing intensively. The properties required for these restorative materials are; physical and chemical properties should be compatible with the dental tissue, the aesthetic and mechanical properties should be satisfactory and its technical application to the cavity should be quick and easy.

Polyacid-modified composite resins, also known as compomers, and resin-modified glass ionomer cements are the most commonly used materials for the restoration of primary teeth; however, both materials are controversial due to their resin content $(1,2)$. The use of traditional glass ionomer cements (GICs), which do not contain resin, is limited due to its moisture sensitivity, fracture resistance, low wear resistance, difficulties in processing materials and lack of aesthetics (3). For these reasons, the search for the restorative material of the primary tooth, which does not contain resin material but is sufficient regarding the physical and mechanical properties until the exfoliation of the primary tooth, continues.

In the recent years, glass hybrid restorative systems (Equia Forte Fil) in the high viscosity GIC group, which are developed to eliminate the existing problems such as moisture sensitivity and low physicalmechanical properties of GICs, have been introduced to the market. Glass hybrid cements are easy-to-use restorative systems with smaller and more reactive silicate particles and acrylic acid molecules with higher molecular weight (4).

Glass carbomer cements, which were developed as a result of the biomimetic studies while the search for an ideal restorative continues, are GIC with carbomer filler and nano-sized flourapatite/ hydroxyapatite speacially designed for its compounds. These materials are chemically hardened and do not contain monomer, resin, metal and Bisfenol A. Heat application and coating its surface with a special varnish is necessary for glass carbomer cements to develop (5).

There are many studies showing that compomer materials are successful alternatives to the composite, amalgam and GICs for the primary teeth class II cavities (6-8). However studies on clinical success of glass carbomer and glass hybrid cements are limited. The aim of this study was to compare the clinical succes of a glass carbomer cement (GCP Glass Fill) and a glass hybrid cement (Equia Forte Fil) in comparison with a compomer material (Dyract XP); due to the concerns over the resin content of compomer materials.

\section{Materials and Methods}

Ethics committee approval required for our research was received from the Board of Research Ethics Committee of Aydın Adnan Menderes University Faculty of Dentistry (protocol no: 2017/002, date: 22.03.2017). The patients and their parents who participated in the study, were informed in details and their written consents were received.

The G*Power program (version 3.1.9.2 for Windows) was used to determine the success rate of the power analysis: the total number of samples detected was $n=24$, for the effect size: 0.576 , with a power: 0.80 and $\alpha$ : 0.05 . Considering the follow-up aspect of the study, total sample size was determined as 35 due to the possibility of loss in the follow-up.

This study was performed on 35 (20 boys, 15 girls) children aged between six to nine years (average 7,5) who applied Aydın Adnan Menderes University, Faculty of Dentistry Department of Pediatric Dentistry and those participants with a behavior rating three or four scores according to the Frankl behavioral scale (9). Patients having at least three primary molar teeth with class II caries not exceeding $1 / 2$ of dentin in the radiographic examination, no indication for pulp therapy or other restorative treatment, no undermining of cusps by caries, no caries lesions extending below the gingival margin, not showing pathological internal or external root resorption, and not exceeding $2 / 3$ of the root of physiological root resorption were included to the study. The children were given oral hygiene instructions and additional dental treatments required for other teeth were done during the study period.

Patients with a history of known or suspected allergy and with a history of bruxism, skeletal and dental malocclusion, congenital developmental defect and those who stated that they could not come to their controls regularly were excluded from the study.

The cavity preparation was performed under water cooling with high-speed diamond burs, under local anesthesia if needed, according to minimally invasive preperation rules. Caries was removed with 
hand tools and steel burs. Rubber-dam (OptiDam ${ }^{\mathrm{TM}}$, Kerr) isolation was used in children who were cooperative and first molar teeth was present in the mouth. Isolation was achieved with cotton roll and suctions in such cases as; the first molar teeth was not present in the mouth; or when parents did not approve the application of rubber dam or in children whose cooperation was affected negatively during the rubber-dam application. In each child three teeth were restored with different materials, by using stratified block randomization and simple randomization methods. The teeth were restored with one of the Compomer material (Dyract XP, Dentsply, Germany), Glass Carbomer Cement (GCP Glass Fill, GCP, Netherlands) or Glass Hybrid Cement (GC Equia Forte Fil, GC Industrial Co, Tokyo, Japan) by using Palodent ${ }^{\circledR}$ Plus matrix system. Restorative materials were applied according to the manufacturers' directions by a single practitioner. Glass carbomer and glass hybrid cements were exposed to heat treatment with a light-curing of GC D-Light Duo LED at $1200-1350 \mathrm{~mW} / \mathrm{cm}^{2}$ light intensity during hardening. For surface protection, both of the glass carbomer and glass hybrid cements were covered with GCP Gloss (GCP, Netherlands) which does not contain resin material. The content of the materials used in the research are provided in details in Table 1.

Restorations were evaluated clinically after one week, six months and 12-months according to the modified United States Public Health Service (USPHS) evaluation criteria (10). Radiographic examination was performed with bite-wing radiographs at sixth and $12^{\text {th }}$ months.

\section{Statistical Analysis}

Statistical analysis was performed using the IBM SPSS Statistics 17.0 (IBM Corporation, Armonk, USA) programme. Cochran's $Q$ test was used to determine the significance of the difference in terms of success rates with respect to monitoring time regarding USPHS criteria. The results for $p<0.05$ were considered statistically significant unless indicated otherwise.

\section{Results}

Statistical evaluation was carried out from the data of 32 patients and 96 (91.42\%) restorations; since three patients did not attend their appointments during the 12-month follow-up. The average age of the patients was $7.5 \pm 1.0$ (year) and 19 (59.4\%) of them were boys and $13(40.6 \%)$ of them were girls. In eight $(25.0 \%)$ cases restorations were performed under rubber-dam isolation.

When overall results in three restorative material groups were evaluated, no statistically significant differences were observed in the incidence of success between the genders $(p>0.0056)$. Also, there was not any significant difference between the restorations performed under rubber dam or cotton rolls isolation ( $p>0.0056)$.

\begin{tabular}{|l|l|l|l|}
\hline Table 1. Materials and their contents used in the study & Pontent & \\
\hline Material & Type & $\begin{array}{l}\text { PDMA, TCB Resin, TEGDMA, trimethacrylate } \\
\text { and dimethacrylate resin, camphoquinone, } \\
\text { ethyl-4benzoate, BHT, UV stabilizator, } \\
\text { strontium-alumino-sodium-floro-fhosphor- } \\
\text { silicate glass, silicon dioxide, stronsium flour, } \\
\text { iron oxide and titanium oxide pigments }\end{array}$ & Dentsply, Germany \\
\hline Dyract XP & Compomer & $\begin{array}{l}\text { PENTA, UDMA, Tresin, D-resin, nanofiller, } \\
\text { photoinitiator, } \\
\text { stabilizators, acetone, cetylamine hidroflorid }\end{array}$ & Dentsply, U.S.A \\
\hline Prime \& Bond & Dentin bonding agent & Floro-aluminosilicate, glass apatite, polyacid & GCP, Netherlands \\
\hline NT & Glass carbomer cement & $\begin{array}{l}\text { Floroaluminosilicate glass, polyacrylic acid } \\
\text { dust, processed glass particule }\end{array}$ & $\begin{array}{l}\text { GC Industrial Co (Tokyo, } \\
\text { Japan) }\end{array}$ \\
\hline GCP Glass Fill & Glass hybrid cement & Modified polysiloxane & GCP, Netherlands \\
\hline GC Equia Forte Fil & - & & \\
\hline GCP Gloss & & & \\
\hline UDMA: 4-trimethylhexane, TCB: Tungsten-carbide burs, TEGDMA: Triethylene glycol-dimethacrylate, BHT: Butylhydroxytoluene, UV: Ultraviolet
\end{tabular}


The results of the restorations regarding modified USPHS criteria during the 12-months follow-up period are shown in Table 2. In terms of overall success, success rates at first week are statistically similar between the three groups of restorative materials $(p=0.174)$, however; there is a statistically

Table 2. The results of the restorations regarding modified United States Public Health Service criteria during the 12-months follow-up period

\begin{tabular}{|c|c|c|c|c|c|}
\hline & & & Compomer & $\begin{array}{l}\text { Glass carbomer } \\
\text { cement }\end{array}$ & $\begin{array}{l}\text { Glass hybrid } \\
\text { cement }\end{array}$ \\
\hline \multirow{9}{*}{ Anatomical form } & \multirow{3}{*}{$1^{\text {st }}$ week } & Alpha & $32(100 \%)$ & $28(87.5 \%)$ & $30(93.8 \%)$ \\
\hline & & Bravo & - & $2(6.3 \%)$ & $1(3.1 \%)$ \\
\hline & & Charlie & - & $2(6.3 \%)$ & $1(3.1 \%)$ \\
\hline & \multirow{3}{*}{$6^{\text {th }}$ month } & Alpha & $31(96.9 \%)$ & $10(31.3 \%)$ & $9(28.1 \%)$ \\
\hline & & Bravo & - & $2(6.3 \%)$ & - \\
\hline & & Charlie & $1(3.1 \%)$ & $20(62.5 \%)$ & $23(71.9 \%)$ \\
\hline & \multirow{3}{*}{$12^{\text {th }}$ month } & Alpha & $31(96.9 \%)$ & $5(15.6 \%)$ & $2(6.3 \%)$ \\
\hline & & Bravo & - & $1(3.1 \%)$ & $2(6.3 \%)$ \\
\hline & & Charlie & $1(3.1 \%)$ & $26(81.3 \%)$ & $28(87.5 \%)$ \\
\hline \multirow{9}{*}{ Marginal integrity } & \multirow{3}{*}{$1^{\text {st }}$ week } & Alpha & $32(100 \%)$ & $30(93.8 \%)$ & $29(90.6 \%)$ \\
\hline & & Bravo & - & - & $2(6.3 \%)$ \\
\hline & & Charlie & - & $2(6.3 \%)$ & $1(3.1 \%)$ \\
\hline & \multirow{3}{*}{$6^{\text {th }}$ month } & Alpha & $31(96.9 \%)$ & $6(18.8 \%)$ & $8(25 \%)$ \\
\hline & & Bravo & - & $6(18.8 \%)$ & $1(3.1 \%)$ \\
\hline & & Charlie & $1(3.1 \%)$ & $20(62.5 \%)$ & $23(71.9 \%)$ \\
\hline & \multirow{3}{*}{$12^{\text {th }}$ month } & Alpha & $30(93.8 \%)$ & 2 (6.3\%) & $3(9.4 \%)$ \\
\hline & & Bravo & $1(3.1 \%)$ & $4(12.5 \%)$ & $1(3.1 \%)$ \\
\hline & & Charlie & $1(3.1 \%)$ & $26(81.3 \%)$ & $28(87.5 \%)$ \\
\hline \multirow{9}{*}{ Marginal discoloration } & \multirow{3}{*}{$1^{\text {st }}$ week } & Alpha & $32(100 \%)$ & $32(100 \%)$ & $31(96.9 \%)$ \\
\hline & & Bravo & - & - & - \\
\hline & & Charlie & - & - & $1(3.1 \%)$ \\
\hline & \multirow{3}{*}{$6^{\text {th }}$ month } & Alpha & $32(100 \%)$ & $21(65.6 \%)$ & $20(62.5 \%)$ \\
\hline & & Bravo & - & - & - \\
\hline & & Charlie & - & $11(34.4 \%)$ & $12(37.5 \%)$ \\
\hline & \multirow{3}{*}{$12^{\text {th }}$ month } & Alpha & 31 (96.9\%) & $10(31.3 \%)$ & 9 (28.1\%) \\
\hline & & Bravo & - & $1(3.1 \%)$ & - \\
\hline & & Charlie & 1 (3.1\%) & $21(65.6 \%)$ & $23(71.9 \%)$ \\
\hline \multirow{9}{*}{ Color match } & \multirow{3}{*}{$1^{\text {st }}$ week } & Alpha & $32(100 \%)$ & $16(50 \%)$ & 23 (71.9\%) \\
\hline & & Bravo & - & $16(50 \%)$ & $8(25 \%)$ \\
\hline & & Charlie & - & - & $1(3.1 \%)$ \\
\hline & \multirow{3}{*}{$6^{\text {th }}$ month } & Alpha & $32(100 \%)$ & $6(18.8 \%)$ & $11(34.4 \%)$ \\
\hline & & Bravo & - & $14(43.8 \%)$ & $8(25 \%)$ \\
\hline & & Charlie & - & $12(37.5 \%)$ & $13(40.6 \%)$ \\
\hline & \multirow{3}{*}{$12^{\text {th }}$ month } & Alpha & $31(96.9 \%)$ & $2(6.3 \%)$ & $2(6.3 \%)$ \\
\hline & & Bravo & - & $8(25 \%)$ & $6(18.8 \%)$ \\
\hline & & Charlie & $1(3.1 \%)$ & $22(68.8 \%)$ & $24(75 \%)$ \\
\hline
\end{tabular}


Table 2 continued

\begin{tabular}{|c|c|c|c|c|c|}
\hline \multirow{9}{*}{ Retention loss } & \multirow{3}{*}{$1^{\text {st }}$ week } & Alpha & $32(100 \%)$ & $29(90.6 \%)$ & 31 (96.9\%) \\
\hline & & Bravo & - & $3(9.4 \%)$ & - \\
\hline & & Charlie & - & - & $1(31 \%)$ \\
\hline & \multirow{3}{*}{$6^{\text {th }}$ month } & Alpha & 31 (96.9\%) & $11(34.4 \%)$ & $9(28.1 \%)$ \\
\hline & & Bravo & - & $9(28.1 \%)$ & 11 (34.4\%) \\
\hline & & Charlie & $1(3.1 \%)$ & $12(37.5 \%)$ & 12 (37.5\%) \\
\hline & \multirow{3}{*}{$12^{\text {th }}$ month } & Alpha & 31 (96.9\%) & $6(18.8 \%)$ & $3(9.4 \%)$ \\
\hline & & Bravo & - & $4(12.5 \%)$ & $6(18.8 \%)$ \\
\hline & & Charlie & $1(3.1 \%)$ & $22(68.8 \%)$ & 23 (71.9\%) \\
\hline \multirow{6}{*}{ Secondary caries } & \multirow{2}{*}{$1^{\text {st }}$ week } & Alpha & $32(100 \%)$ & $32(100 \%)$ & $32(100 \%)$ \\
\hline & & Bravo & - & - & - \\
\hline & \multirow{2}{*}{$6^{\text {th }}$ month } & Alpha & $32(100 \%)$ & $27(84.4 \%)$ & $29(90.6 \%)$ \\
\hline & & Bravo & - & $5(15.6 \%)$ & $3(9.4 \%)$ \\
\hline & \multirow{2}{*}{$12^{\text {th }}$ month } & Alpha & 31 (96.9\%) & $12(37.5 \%)$ & $9(28.1 \%)$ \\
\hline & & Bravo & $1(3.1 \%)$ & $20(62.5 \%)$ & $23(71.9 \%)$ \\
\hline
\end{tabular}

significant difference between the clinical success of the materials at sixth and $12^{\text {th }}$ months $(p<0.001)$ (Figure 1). The overall success rates are significantly lower in glass carbomer cement and glass hybrid cement groups, when compared to the compomer group $(p<0.001)$. The overall success rates of glass carbomer cement and glass hybrid cement groups are statistically similar at sixth and $12^{\text {th }}$ month $(p=0.774$ and $p=0.687$ respectively) (Table 3 ).

\section{Discussion}

As concerns over the biocompatibility of resinbased materials have increased over the last few years, there has been an increasing trend towards resin-free, biocompatible, remineralization-enhancing

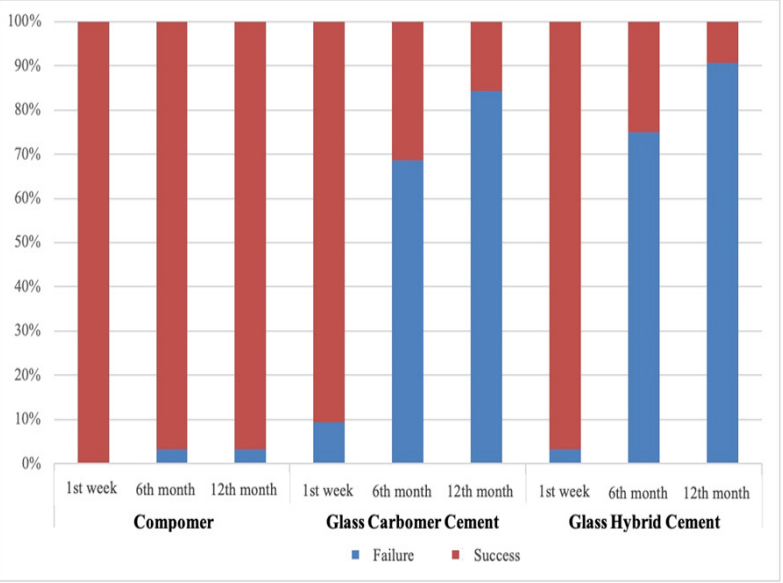

Figure 1. Overall success rates of the three groups

Table 3. Overall success rates according to materials and follow-up times

\begin{tabular}{|l|l|l|l|l|} 
& Compomer (n=32) & $\begin{array}{l}\text { Glass carbomer cement } \\
(\mathbf{n = 3 2 )}\end{array}$ & Glass hybrid cement (n=32) & p-value +q \\
\hline $1^{\text {st }}$ week & $32(100 \%)$ & $29(90.6 \%)^{\mathrm{a}, \mathrm{b}}$ & $31(96.9 \%)^{\mathrm{a}, \mathrm{b}}$ & 0.174 \\
\hline $6^{\text {th }}$ month & $31(96.9 \%)^{\mathrm{A}, \mathrm{B}}$ & $10(31.3 \%)^{\mathrm{A}, \mathrm{a}}$ & $8(25 \%)^{\mathrm{B}, \mathrm{a}}$ & $<0.001$ \\
\hline $12^{\text {th }}$ month & $31(96.9 \%)^{\mathrm{A}, \mathrm{B}}$ & $5(15.6 \%)^{\mathrm{A}, \mathrm{b}}$ & $3(9.4 \%)^{\mathrm{B}, \mathrm{b}}$ & $<0.001$ \\
\hline$p$-value $¥ \boldsymbol{\eta}$ & 0.368 & $<0.001$ & $<0.001$ & - \\
\hline
\end{tabular}

- +Comparisons between materials within each follow-up time, ¥Comparisons between follow-up times in material groups, ๆCochran's Q test, results for $p<0.0167$ were considered statistically significant according to the Bonferroni Correction, ${ }^{A} T$ The difference between the Compomer group and the Glass Carbomer Cement group is statistically significant $(p<0,001),{ }^{B}$ The difference between the Compomer group and the Glass Hybrid Cement group is statistically significant $(p<0.001)$, ${ }^{a}$ The difference between

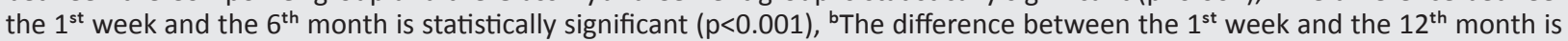
statistically significant $(p<0.001)$ 
restorative materials $(11,12)$. GICs are one of the most frequently used restorative materials in pedodontics. However; the weak physical and mechanical properties of conventional GIC, its sensitivity to dryness and moisture, lack of aesthetics limits its use (13). Manufacturers have introduced restorative materials such as glass carbomer cement and glass hybrid cement in order to eliminate the negative features of GIC's and provide alternative restorative materials used frequently in the posterior region $(3,14)$. In this clinical study, it was aimed to examine the clinical success of these biocompatible materials compared to a compomer material, which has been widely used in primary teeth.

The negative impact of external effects on the material during the long-lasting hardening reaction of GICs is one of the most important disadvantages and to reduce this critical time as much as possible is desired. It is thought that heat polymerization shortens this period and enables GIC to reach optimum physical properties in a shorter time $(15,16)$. With all this information and according to the recommendation of the manufacturer, in order to obtain the best clinical results; glass carbomer and glass hybrid cement restorative materials were processed with heat through D-Light Duo LED Curing Light light source of $1200-1350 \mathrm{~mW} / \mathrm{cm}^{2}$ light power for 90 seconds, in our study.

Moisture isolation can be provided by the use of rubber dam or cotton rolls together with the suctions. In eight patients who participated our study, isolation was provided with rubber-dam and suctions; and for the rest of the patients cotton rolls and suctions were used. It has been reported that the use of rubber dam or cotton rolls for isolation had the same effect on the clinical success of the restorations (17-19). Similarly, in our study, no significant difference was found between the restorations done with either rubber dam or cotton rolls.

USPHS criteria, first published in 1971 and reprinted in 2005, is still the most widely used system to evaluate the important features of dental restorations (10) so; in our study, modified USPHS criteria was used to evaluate restorations.

The results of our clinical study has shown that, the rate of clinically successful restorations at the end of 12 months were $96.9 \%$ in the Dyract XP group, $15.6 \%$ in the GCP Glass Fill group and $9.4 \%$ in the Equia
Forte group. In the literature there are many studies showing that compomer materials are successful alternatives to the composite, amalgam and GICs for the primary teeth class II cavities (6-8). Pascon et al. (7) who compared the clinical success of compomer and composite restorations for 24 months; have concluded that the compomer groups showed high clinical success in both class I and class II restorations when compared to composite restorations. Welbury et al. (20) compared the clinical success of a compomer material with a glass ionomer material in primary molar teeth restorations. They reported that after 42 month follow up compomer restorations were significantly more successful than the glass ionomer restorations. Similarly Duggal et al. (8) have reported high retention rates of compomer restorations in class II primary molar teeth when compared with amalgam restorations. In our study the compomer material group showed $96.9 \%$ success after 12 -months and this result was significantly better than the other two restorative materials.

When the clinical studies examining the GICs were evaluated, it has been reported that the annual failure rates for class I restorations vary between $0 \%$ and $17 \%$ and for the class II restorations these rates vary between $2.2 \%$ and $25.8 \%$. One of the reasons for the varying failure rates in the studies may be the different types of GICs used in the studies (21). The two types of GICs used in our study showed much more higher failure rates than these studies. Although the number of in-vivo studies using GCP Glass Fill is very low, studies evaluating the clinical performance of this material have shown that it has significantly lower clinical success (36\%) than a compomer material $(56 \%)$ in class II restorations $(22,23)$. Similarly in our study GCP Glass Fill restorations were found to be unsuccessful compared to the Dyract XP restorations and have the same clinical success as Equia Forte Fil. The failure of the GCP Glass Fill restorations may be due to the low mechanical properties and the surface covering that cannot protect the material sufficiently.

Success of high viscosity GICs in permanent teeth was evaluated in a few clinical trials and acceptable retention performance was reported (24-26). The studies evaluating the clinical performance of high viscosity glass ionomers in primary teeth are fewer. De França et al. (22) compared the survival rate of atraumatic restorative treatment (ART) class II 
restorations in primary teeth, performed with glass carbomer cement and a high-viscosity GIC. After 12 months, the overall success rates of glass carbomer cement and high-viscosity GIC groups were $56 \%$ and $86 \%$, respectively and this difference was found to be statistically significant. Olegário et al. (23) have reported a survival rate of $56 \%$ after three years of occlusoproximal ART restoration with high-viscosity GIC. The results of these studies do not fully agree with the results of our study. The reason for the low clinical success results in Equia Forte Fil group in our study may be contributed to the covering applied over the material. During the application of restorations, the recommendations of the manufacturers have been followed but as a result of our search for alternative resin-free, biocompatible restorative material for primary teeth, instead of using resin containing surface covering Equia Forte Coat, the surface of the Equia Forte Fil restorations were covered with resinfree silicone-containing surface covering GCP Gloss. This may have negative effects on the mechanical properties of the material (27). Another group with Equia Forte Coat coverage could be added to find out the effect of resin covering on Equia Forte Fil, and this could be the limitation of our study.

\section{Conclusion}

Widely used compomer materials in primary teeth restorations have high clinical success rates but they have resin content. In this study we aimed to find an alternative restorative material for primary teeth restorations with no resin content. However; it can be concluded that neither GCP Glass Fill nor Equia Forte Fil applied without resin covering was found to be a good alternative to Dyract XP. Different clinical studies with long-term follow-ups are needed regarding this issue.

\section{Ethics}

Ethics Committee Approval: Ethics committee approval required for our research was received from the Board of Research Ethics Committee of Aydın Adnan University Faculty of Dentistry (protocol no: 2017/002, date: 22.03.2017).

Informed Consent: The patients and their parents who participated in the study, were informed in details and their written consents were received.

Peer-review: Externally peer-reviewed.

\section{Authorship Contributions}

Concept: I.S., Design: I.S., Ş.E., Supervision: I.S., Ş.E., Fundings: I.S., S..E., Materials: Ş.E., Data Collection or Processing: Ş.E., Analysis or Interpretation: I.S., Ş.E., Literature Search: Ş.E., Critical Review: I.S., Ş.E., Writing: I.S., Ş.E.

Conflict of Interest: No conflict of interest was declared by the authors.

Financial Disclosure: This work was supported by Aydın Adnan Menderes University Research Fund (project no: DHF-17001).

\section{References}

1. Nicholson JW, Czarnecka B. The biocompatibility of resinmodified glass-ionomer cements for dentistry. Dent Mater 2008; 24: 1702-8.

2. Geurtsen W. Biocompatibility of resin-modified filling materials. Crit Rev Oral Biol Med 2000; 11: 333-55.

3. Çapan BŞ, Akyüz $\mathrm{S}$. Çocuk diş hekimliğinde fluorid salınımı yapan güncel restoratif materyaller. Clin Exp Health Sci 2016; 6: 129-34.

4. Collado-González M, Pecci-Lloret MR, Tomás-Catalá CJ, GarcíaBernal D, Oñate-Sánchez RE, Llena C, et al. Thermo-setting glass ionomer cements promote variable biological responses of human dental pulp stem cells. Dent Mater 2018; 34: 932-43.

5. Dülgergil ÇT, Ertürk AT. Diş hekimliği restoratif uygulamalarinda yeni materyal olarak cam karbomer simanlar. AÜ Dişhek Fak Derg 2016; 26: 517-23.

6. Gross LC, Griffen AL, Casamassimo PS. Compomers as class II restorations in primary molars. Pediatr Dent 2001; 23: 24-7.

7. Pascon FM, Kantovitz KR, Caldo-Teixeira AS, Borges AFS, Silva TN, Puppin-Rontani RM, et al. Clinical evaluation of composite and compomer restorations in primary teeth: 24-month results. J Dent 2006; 34: 381-8.

8. Duggal $M$, Toumba K, Sharma N. Clinical performance of a compomer and amalgam for the interproximal restoration of primary molars: a 24-month evaluation. Br Dent J 2002; 193: 339-42.

9. Ay S, Kambek S, Cevit Ö, Öztürk M, Yeler H, Acar G. Çocuklarda diş çekiminde sedasyon için intranazal midazolam kullaniminin değerlendirilmesi. CÜ Dişhek Fak Derg 1999; 2: 71-5.

10. Taviloğlu E. 2 yil ve daha uzun süre ağizda kalmiş arka bölge direkt ve indirekt kompozit restorasyonlarin 10 yillik klinik değerlendirilmesi. Quintessence 2011; 5: 17-31.

11. Schwengberg $S$, Bohlen $H$, Kleinsasser $N$, Kehe $K$, Seiss $M$, Walther $U$, et al. In vitro embryotoxicity assessment with dental restorative materials. J Dent 2005; 33: 49-55.

12. Kanik Ö, Türkün LŞ. Restoratif cam iyonomer simanlarda güncel yaklaşımlar. EÜ Dişhek Fak Derg 2016; 37: 54-65.

13. Celik EU, Ermis B. Koruyucu rezin uygulamasının yüksek viskoziteli geleneksel cam iyonomer simanın mikrosertliği üzerine etkisinin in vitro olarak değerlendirilmesi. Cumhuriyet Dent J 2008; 11: 91-5. 
14. Altan H, Altan A, Arslanoğlu Z. Glass ionomer cement, derivates and glass carbomer cement. J Clin Sci 2013; 6: 1319-22.

15. Gorseta K, Glavina D. Thermo-cured glass ionomer cements in restorative dentistry. J Istanb Univ Fac Dent 2017; 51(3 Suppl 1): 122-7.

16. Gorseta K, Glavina D, Skrinjaric I. Influence of ultrasonic excitation and heat application on the microleakage of glass ionomer cements. Aust Dent J 2012; 57: 453-7.

17. Carvalho TS, Sampaio FC, Diniz A, Bönecker M, Van Amerongen WE. Two years survival rate of Class II ART restorations in primary molars using two ways to avoid saliva contamination. Int J Paediatr Dent 2010; 20: 419-25.

18. Çelik Ç, Özgünaltay $G$, Attar N. Çürüksüz servikal lezyonlara uygulanan akışkan restoratif materyallerin kenar uyumu ve yüzey özelliklerinin SEM ile değerlendirilmesi. Hacettepe Dişhek Fak Derg 2007; 31: 79-88.

19. Welbury R, Raadal M, Lygidakis N. EAPD guidelines for the use of pit and fissure sealants. Eur J Paediatr Dent 2004; 5: 179-84.

20. Welbury R, Shaw A, Murray J, Gordon P, McCabe J. Paediatric dentistry: Clinical evaluation of paired compomer and glass ionomer restorations in primary molars: final results after 42 months. Br Dent J 2000; 189: 93-7.
21. Hickel R, Kaaden C, Paschos E, Buerkle V, García-Godoy F, Manhart J. Longevity of occlusally-stressed restorations in posterior primary teeth. Am J Dent 2005; 18: 198-211.

22. De França L, Condeixa CM, Schubert EW, Martins AS, Loguercio $A D$, Reis $A$, et al. Randomized clinical trial of art class II restorations using two glass ionomer cements: one-year followup. Pediatr Dent 2018; 40: 98-104.

23. Olegário IC, Hesse D, Mendes FM, Bonifácio CC, Raggio DP. Glass carbomer and compomer for ART restorations: 3-year results of a randomized clinical trial. Clin Oral Investig 2018; 23: 1-10.

24. Friedl K, Hiller KA, Friedl KH. Clinical performance of a new glass ionomer-based restoration system: a retrospective cohort study. Dent Mater 2011; 27: 1031-7.

25. Gurgan S, Kutuk ZB, Ergin E, Oztas SS, Cakir FY. Clinical performance of a glass ionomer restorative system: a 6-year evaluation. Clin Oral Investig 2017; 21: 2335-43.

26. Gurgan S, Kutuk Z, Ergin E, Oztas S, Cakir F. Four-year randomized clinical trial to evaluate the clinical performance of a glass ionomer restorative system. Oper Dent 2015; 40: 134-43.

27. De Aguiar Grossi J, Cabral RN, Ribeiro APD, Leal SC. Glass hybrid restorations as an alternative for restoring hypomineralized molars in the ART model. BMC Oral Health 2018; 18: 65-73. 